\title{
Elk conflict with beef and dairy producers poses wildlife management challenges in northern California
}

\author{
$\underline{\text { Adam R. Hanbury-Brown }}^{1}$, Jeffery W. Stackhouse ${ }^{2}$ and Luke T. Macaulay $^{3,4}$
}

\begin{abstract}
Large terrestrial wildlife negatively impacts agricultural livelihoods on all continents except Antarctica. There is growing recognition of the need to reconcile these impacts to achieve socially and ecologically sustainable wildlife conservation agendas. Elk populations in northern California are estimated to have doubled in the past 35 years, marking a conservation success, but also increasing forage loss and damage to infrastructure on private land. Wildlife managers are pursuing the goal of increasing elk numbers on public lands, but elk are preferentially utilizing private pasture and rangeland, driving conflict with beef and dairy producers. We conducted 17 semistructured interviews with private landowners, primarily beef and dairy producers, in northern California to understand their experiences and reactions to elk conflict and state wildlife management. Landowners report that elk density on private rangeland has steadily increased in recent years and poses a threat to their businesses due to loss of forage, damage to fences, and the corresponding liability risk posed by breached fences and errant cattle. The absence of crop and forage loss compensation, difficulty obtaining depredation permits, and low harvest quotas for recreational hunting limit landowner mitigation options and foster resentment toward the state wildlife agency. Most landowners believe that current elk management policies, including restricted hunting opportunities, do not adequately address elk conflict, creating novel challenges for wildlife officials tasked with reconciling elk restoration goals with a variety of stakeholders experiencing economic losses and threats to rural livelihoods. We discuss these issues in the context of common wildlife management challenges, such as building social capital, defining tolerable impacts, and building institutional capacity for alternative solutions within rigid regulatory frameworks. We draw upon environmental economics and common-pool resource theory to suggest that a rethinking of elk management based on local conditions, facilitating damage compensation mechanisms while reducing transaction costs, and increasing participation of local stakeholders in decision making might improve outcomes.
\end{abstract}

Key Words: elk conflict; hunting; northern California; pasture depredation; private land; rangeland; wildlife conflict; wildlife management

\section{INTRODUCTION}

\section{Background}

Conflict between agricultural livelihoods and wildlife is a pervasive issue facing wildlife managers and conservation practitioners globally. Crop raiding and pasture loss from large terrestrial mammals negatively impacts agricultural producers on all continents except Antarctica (Nyhus et al. 2016). Wildlife damages from free-roaming deer and elk in North America and Europe have negatively impacted agricultural communities for decades and shaped attitudes toward wildlife and conservation (Conover et al. 1995, Bullock et al. 1998, van Tassel et al. 1999, Heydlauff et al. 2006, Hegel et al. 2009, Walberg et al. 2017). Recovering elk and deer populations in Arizona, Minnesota, Wisconsin, New Mexico, the Eastern USA, and some parts of Canada have resulted in significant damages to crops, fencing, and stored feed (Yoder 2002, Heydlauff et al. 2006, Stewart et al. 2007, Gooding and Brook 2014, DeVore et al. 2016, Walberg et al. 2017, Flaherty et al. 2019). Understanding the drivers and potential solutions to these issues within particular socialecological contexts is important for crafting appropriate policy to reduce pressure on vulnerable wildlife populations without jeopardizing agricultural communities and creating resentment toward conservation.

The management of elk (Cervus elaphus) in northern California illuminates many of the challenges associated with achieving human-wildlife coexistence. Elk were nearly extirpated from
California in the late 19th century due to market hunting (Harper et al. 1967). Between 1985 and 2000, the California Department of Fish and Wildlife (CDFW) reintroduced more than 350 elk to northern California (CDFW 2018), initiating a successful restoration effort. The CDFW reintroduced Tule elk in response to state and federal legislation backed by preservationists and introduced Roosevelt elk in response to local hunting interests (Gogan et al. 2013). The original criteria for elk reintroduction locations included forage availability, public accessibility, and a low potential for damage to private property (CDFW 2018). Over the last 35 years, elk numbers are estimated to have doubled (Fig. $1 a)$, and their range is expanding into areas well beyond the sites that initially met the reintroduction criteria. The quality of elk forage on public land has decreased since elk reintroductions began because timber harvest rates are now less than a quarter of what they were in the 1980s, and many shrublands are senescent due to fire suppression (CDFW 2018, Rowland et al. 2018). The outcome of these ecosystem-scale changes is that elk are now reoccupying a landscape mosaicked with private livestock ranches, dairies, forestry operations, and recreational properties, creating human-elk conflict described by state wildlife managers as "significant in some areas" (CDFW 2018: 4). The CDFW's 2018 Elk Management Plan includes the dual objectives to "increase elk populations by at least $10 \%$ statewide where humanelk conflicts are expected to be minimal" and to "reduce incidents of human-elk conflicts on private property by at least $25 \%$ " (CDFW 2018: 14). Simultaneously satisfying these goals is

${ }^{1}$ Energy and Resources Group, University of California, Berkeley, ${ }^{2}$ University of California Cooperative Extension, ${ }^{3}$ University of Maryland Extension, University of Maryland, ${ }^{4}$ Department of Environmental Science, Policy \& Management, University of California, Berkeley 
challenging because elk select private land (Rowland et al. 2018) and agricultural areas (Devore et al. 2016) where active land and vegetation management provides nutritious forage and early seral vegetation preferred by elk.

Fig. 1. (a) Statewide elk population estimates (1965-2017; green $=$ Roosevelt elk; orange $=$ Tule elk; blue $=$ Rocky Mountain elk). (b) The current range of elk in northern California (green $=$ Roosevelt elk; orange $=$ Tule elk; blue $=$ Rocky Mountain elk). The counties with bold outlines comprise the "North Coast" and is our study area. Reproduced from CDFW 2018.
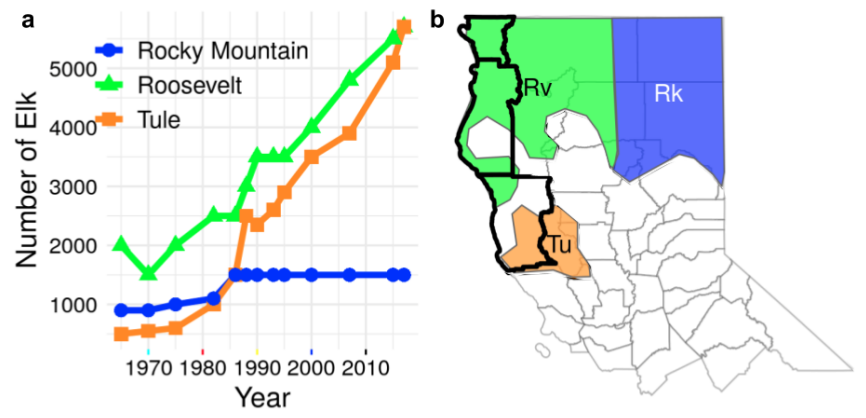

Elk depredation of crops and pastureland has caused economic losses to agricultural communities throughout North America (van Tassel et al. 1999, Heydlauff et al. 2006, Hegel et al. 2009, Walberg et al. 2017), but is underinvestigated in California, Oregon, and Washington despite mounting evidence of elk conflict in these areas. In 2018, the Washington Department of Fish and Wildlife (WDFW) was forced to update their elk management plan with a more aggressive strategy to reduce elk depredation of pasture in Skagit County (WDFW 2018) amid pressure from the local Board of Commissioners. Elk conflict is becoming particularly severe on California's North Coast, which encompasses Humboldt, Del Norte, and Mendocino Counties (Fig. 1b). This region is home to 253,744 ha of rangeland (University of California Cooperative Extension (UCCE) 2019) supporting roughly $\$ 260$ million in beef, dairy, and other pasturebased industries (California Department of Food and Agriculture (CDFA) 2016, Humboldt County Department of Agriculture (HCDA) 2016). Many North Coast cattle ranches are multigenerational, family-owned properties and raise livestock on the area's grasslands, supporting both food production and rural livelihoods. Private pasturelands in Humboldt and Del Norte counties are heavily impacted by expanding populations of Roosevelt elk (Cervus elaphus roosevelti), which weigh between 575 and 1300 pounds (Robb and Bethge 2001, Rocky Mountain Elk Foundation (RMEF) 2019). Despite their utilization of private land, elk are legally owned by nobody (res nullius), and their management, including harvest and potential relocation, is regulated by the state (Favre 2003). This limits landowner damage mitigation options to those prescribed by California's limited legal hunting opportunities and defensive measures that do not reduce local elk populations. Many states have compensation programs and wildlife depredation permits to address crop damages by elk and other ungulates (Wisconsin Farm Bureau 2020, Minnesota Department of Agriculture (MNDA) 2020). Neighboring Nevada provides hunting opportunities designed specifically to address deer and antelope conflict (Nevada Department of Wildlife (NDW) 2020), and Oregon recently proposed legislation to hunt elk for the purpose of damage mitigation (Oregon State Legislature 2020). In contrast, California does not have a hunting program specifically designed for this purpose, nor does it have a crop damage compensation program. The CDFW is legally allowed to issue depredation permits to kill elk only if the department (a) has verified satisfactory evidence of the damage or destruction, (b) has determined the minimum population level needed to maintain the herd, and (c) can ensure that the permit will not reduce the local herd below that minimum (State of California. 2007).

\section{Management Challenges and Missing Information}

California's 2018 Elk Management Plan states that regulated hunting is the primary tool to alleviate elk conflict (CDFW 2018), but there are historical, institutional, and political hurdles portending difficulty with this strategy: conservative harvest quotas (CDFW 2018, CDFW 2019b) are set to expand rather than control the population, raising harvest quotas requires an environmental impact report supported by multiyear population surveys, environmental organizations are likely to oppose raising quotas (Center for Biological Diversity 2016), and current hunting programs are not designed for damage alleviation or compensation (CDFW 2019a, b). The Private Lands Management (PLM) program and the Shared Habitat Alliance for Recreational Enhancement (SHARE; CDFW 2019b) program both facilitate hunting on private land. The PLM program was established with the goal of supporting wildlife populations through habitat improvement incentives (CDFW 2019a), and SHARE's focus is to increase public hunter access to private land, not to cull herds (CDWF 2019b). Under the PLM program, CDFW allocates hunting tags to enrolled landowners in exchange for targeted habitat improvement projects. Landowners can sell their tags to hunters who pay to hunt on their lands. Under the more recent SHARE program, tags are issued to the public through a lottery system, and public hunters gain access to enrolled private properties. The SHARE program decreases hunting costs for the public, but also reduces landowner capacity to financially offset elk damages because landowners are not permitted to sell elk tags directly to the highest bidder. Given that hunting is CDFW's primary strategy for alleviating elk damages (CDFW 2018), it is important to understand landowner perceptions and experiences with these programs.

California Fish and Game Code 1801 (g) mandates CDFW to "alleviate economic losses [from wildlife] in a manner designed to bring the problem within tolerable limits." Defining tolerable limits is difficult due to a lack of studies on the extent and nuances of landowner experiences of elk conflict on the North Coast. Improved understanding of impacts to landowners may help wildlife managers navigate the potentially conflicting management goals of increasing herds while alleviating conflict. This study provides a starting point for reconciling this information gap by answering the following questions: (1) what is the nature and magnitude of elk conflict on the North Coast (Fig. 1b delineates the three-county study area)? (2) How are landowners reacting to this conflict? and (3) What are landowner experiences with state-level elk management? Answering these questions will: (1) disseminate lessons learned from interviewees experiencing elk damage to those who may be on the cusp of 
experiencing damages or enrolling in hunting programs, (2) illuminate nuanced aspects of the social and economic consequences of wildlife conflict for managers and decision makers, and (3) identify key themes and potential solutions to wildlife conflict more broadly.

\section{METHODS}

\section{Semistructured Interviews with Agricultural Producers}

We chose semistructured interviews because they offer an effective means of gathering nuanced, context-specific, and culturally informed data of understudied phenomena and have been specifically identified as important for understanding rangeland socioecological systems (Sayre 2004). Between January and July 2019, we conducted 17 semistructured interviews with private landowners and private land managers representing ca. 200,000 ha distributed throughout the North Coast in Humboldt, Del Norte, and Mendocino Counties (and one in Monterey). Eleven of the interviewees consented to audio recording. Our study population included North Coast private landowners and land managers engaged in livestock, dairy, timber, or agriculture production within the estimated range of free-roaming elk (Fig. 1b). Interviewees were purposively recruited in areas of known elk occupancy because understanding elk conflict was our focus. Most ranchers and farmers in our study area do not regularly collaborate with academic researchers and are reticent to discuss their operations without a trusted referral from within the community. Therefore, as is common in studies of hard-to-reach populations, our population did not have an accessible sampling frame from which to draw a statistically random sample. To overcome this, we used established qualitative methods whereby interviewees were selected from (1) a "convenience sample" (Ilker et al. 2016) of landowners known to us through engagement with the UCCE network (an educational program designed to help people, traditionally farmers and ranchers, use research-based knowledge to improve their lives; UCCE 2019) and (2) "snowball sampling," where prior interviewees referred us to subsequent interviewees (Barboza et al. 2016, Herman-Mercer et al. 2016). This methodology is generally not intended to capture a quantitatively representative sample, and therefore, is not congruent with statistical analysis, but is nevertheless considered a valuable approach to understanding complex social science issues and is a useful tool to inform development of future quantitative studies. This approach has been successfully applied to social-ecological systems in a variety of contexts (Allen et al. 2015, D'Anna and Murray 2015, Nahuelhual et al. 2016, Crosman et al. 2019).

The majority of interviewees were ranchers, including beef ( $n=$ $11)$ and dairy $(n=3)$ producers, and forestry companies $(n=2)$ and row crop growers $(n=1)$ were also represented to a lesser extent. We found 17 interviews to be a sufficient sample size because we stopped learning new information on key themes pertinent to our research questions after roughly 15 interviews, a phenomenon known as "reaching saturation" (Faulkner and Trotter 2017, Herman-Mercer et al. 2016) and because we focused on large properties (126-20,000+ ha, median 521), which allowed us to sample $13 \%$ of the private land (CalLands 2018) in our study area. Evergreen forest accounted for an average of 53\% of land cover across the counties we sampled, and the remaining land was dominated by grasslands and shrublands where beef and dairy production is most common (CalLands 2018). Nine interviews took place in person at the landowner's property, and eight were conducted by telephone. Interviews were guided by a questionnaire (Append. 1) that included questions about their property characteristics, businesses, experiences with elk and elk conflict, experience with state hunting programs, and their broader perceptions of elk management. The semistructured interview framework fostered open-ended discussion, allowing the interviewee to guide conversation in the direction they felt was most pertinent to understanding their experience of elk conflict and management. After in-person interviews, landowners showed researchers their properties to view resident elk and elk damages, allowing us to witness elk herds, elk tracks and scat, and damage to fences where they bisected well-used elk trails. This helped to anecdotally corroborate landowner reports of elk occupancy. Interviews and site visits were thorough, taking between 1 and 3 hours to complete. We also engaged in participant observation at a public meeting on elk conflict hosted by the CDFW and had three targeted conversations with local CDFW personnel throughout the study period to understand their goals, constraints, and perspectives. The public meeting was attended by approximately 30 people, most of whom were experiencing elk conflict.

We used RQDA software (Huang 2018) and standard qualitative research methods for transcribing, coding, and developing themes from the interview data. All protocols for interviewee identification, recruitment, questionnaire design, and confidentiality received Institutional Review Board approval through the University of California Berkeley Office for the Protection of Human Subjects.

\section{Estimating Elk-induced Pasture Loss}

Prior synthesis of natural resource monitoring typologies reveals a spectrum of approaches that vary from sophisticated efforts by trained specialists to collaborative and autonomous local monitoring by nonprofessionals (Danielsen et al. 2009). The latter end of this spectrum is most applicable in cases where local participants have a particularly strong interest in the status of the resource and when other forms of data are not available. Official data on elk movements and population size were not available on a spatiotemporal scale required to quantify elk occupancy of each private property. Therefore, we asked ranchers to estimate (1) the number of elk that visited or resided on their land $\left(n_{\text {elk }}\right)$ and (2) elk occupancy of their land on two temporal scales: (a) the fraction of the year that elk are in the vicinity of the private holding $\left(F_{l}\right)$ and $(b)$ the fraction of time elk spend on the private holding within times of the year that they are seasonally present $\left(F_{2}\right)$. To calculate the corresponding economic impact of elkinduced pasture loss $\left(L_{\text {pasture }}\right)$, we used the standard "animal unit equivalent" method (AUEs; Natural Resources Conservation Service (NRCS) 2016; see Append. 2 for parameter values and sources) and the current pasture rental rate on the North Coast (\$25 per animal unit month; CDFA 2016). For example, assuming a typical Roosevelt elk on the North Coast is 0.8 AUEs (Append. 2 ), the cost of harboring it full time is approximately $\$ 25 * 0.8$ AUEs $=\$ 20$ per month. Therefore, a herd of 50 elk on a ranch for 6 months per year would cost the rancher $\$ 6,000$ annually; equivalent to $\$ 12 \mathrm{ha}^{-1} \mathrm{yr}^{-1}$ for the median property size in our sample. In sum, the annual cost of elk-induced pasture loss for a rancher suffering Roosevelt elk depredation is calculated as: 
Table 1. Key findings and management implications

\begin{tabular}{|c|c|c|}
\hline \multirow[t]{2}{*}{ Key findings from interviews } & \multicolumn{2}{|l|}{ Management implications and recommendations } \\
\hline & For wildlife professionals & For ranchers \\
\hline Elk conflict is increasing & Current hunting is not alleviating conflict & Reduced stocking density may be necessary in short term \\
\hline $\begin{array}{l}\text { Forage depredation and fence damage are } \\
\text { primary concerns }\end{array}$ & $\begin{array}{l}\text { Damage prevention or compensation is } \\
\text { needed }\end{array}$ & Ad hoc mitigation practices have not solved the problem \\
\hline Fence damage increases liability risk for ranchers & $\begin{array}{l}\text { Addressing liability of elk-damaged fences is } \\
\text { crucial }\end{array}$ & Check fences adjacent to roads most frequently \\
\hline $\begin{array}{l}\text { Some properties not suitable for recreational } \\
\text { hunting }\end{array}$ & Additional management tools are needed & $\begin{array}{l}\text { Check eligibility for hunting programs, assess risks on your } \\
\text { property }\end{array}$ \\
\hline Public hunting access is a concern & $\begin{array}{l}\text { Disseminate terms and conditions of } \\
\text { SHARE more widely }\end{array}$ & $\begin{array}{l}\text { Orienting hunters to safety hazards on private land can } \\
\text { promote safe hunting behavior }\end{array}$ \\
\hline $\begin{array}{l}\text { Ranchers perceive injustice in their } \\
\text { disproportionate financial support of elk and } \\
\text { want immediate action }\end{array}$ & $\begin{array}{l}\text { Maintaining trust and collaboration with } \\
\text { landowners is essential for effective } \\
\text { management }\end{array}$ & $\begin{array}{l}\text { Meaningful action may require an elevation of the discussion } \\
\text { to legislators in collaboration with local agencies }\end{array}$ \\
\hline
\end{tabular}

$$
L_{\text {pasture }}=\left(N_{\text {elk }}\right)\left(F_{1}\right)\left(F_{2}\right)(0.8 A U E s)(\$ 25)\left(12 \text { months } y r^{-1}\right)
$$

Four landowners had recorded local population estimates based on visual counts in partial fulfillment of their PLM contracts with CDFW, whereas the others reported elk numbers more informally based on their recall of daily experiences living full time with elk herds on their property. The accuracy of landowner reports likely varied by context. Where herds are resident, partially habituated, or forage in open pastures $(n=11)$, we presume that estimating the number of elk on their land is relatively easier than where holdings contain large forested areas and seasonal elk occupancy $(n=4)$. Similar wildlife observations from nonwildlife professionals have been used to study the risk of brucellosis transmission (Kauffman et al. 2016), conduct citizen science wildlife surveys (Lee et al. 2006), estimate wildlife damages (Vedeld et al. 2016), draft PLM contracts with CDFW (CDFW 2008), and help CDFW in their broader elk research on the North Coast (CDFW 2020). However, accurately estimating wildlife numbers is notoriously difficult even in multiyear studies conducted by wildlife professionals. As such, we do not intend for the data in our study to provide accurate population estimates or to implement crop damage compensation payments, but rather to provide insight into elk pressure and an initial range of the economic impacts of elk-induced pasture loss experienced at the scale of individual properties.

\section{RESULTS}

The key findings and management implications of our interviews are summarized in Table 1 and are discussed in the following sections.

\section{Pasture Loss and Degradation}

Elk depredation of pasture was the primary source of elk conflict across all interviewees and significantly impacted the beef and dairy producers. The median number of elk reported to occupy interviewee land was 125 and ranged from 16-300 $(n=15)$, which equated to a range of densities between $0.02-0.98$ elk per hectare (Fig. 2). All but one of the interviewees noted seeing more elk in recent years. Nine of the 17 interviewees reported that elk were present on their land all year round, and the remaining eight reported that elk were present seasonally $(50-80 \%$ of the year; Fig. 3). In cases where elk were seen only during particular seasons, the within-season occupancy of private land also varied by landowner (Fig. 3).
Fig. 2. Elk density on interviewee land. Elk density is derived from landowner reports of elk abundance on their land.

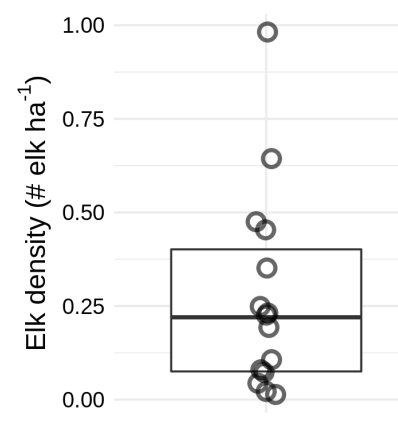

Fig. 3. The temporal aspects of elk occupancy on private land. This includes both the fraction of the year that elk are in the vicinity of the private holding (y axis; F1 in Eq. 1) and the fraction of time elk spend on the private holding within times of the year that they are seasonally present (x axis; F2 in Eq. 1). Symbol size is proportional to elk density.

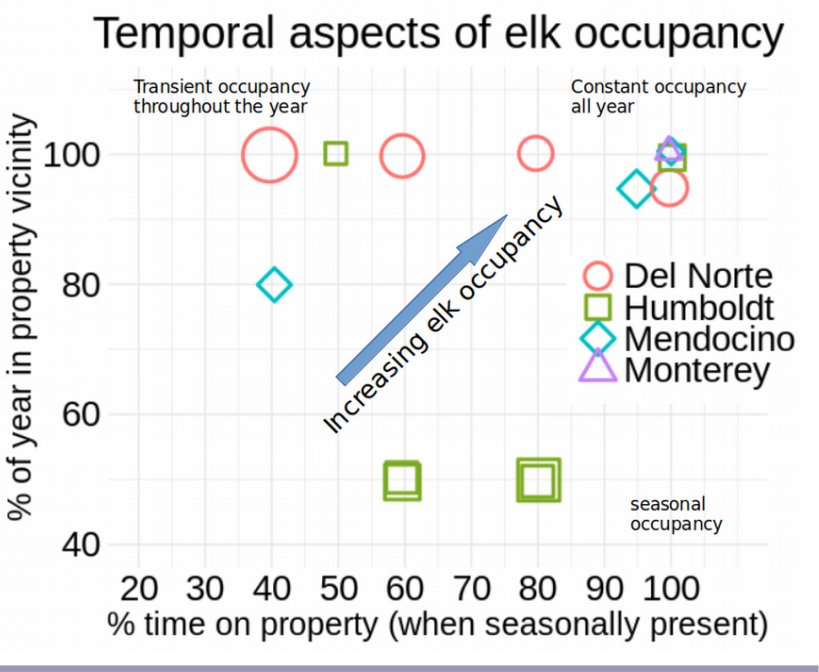


Because of the difficulty of estimating the economic impact of elk depredation of pasture, most interviewees did not try to quantify this value themselves. Using the methods described above, we estimated the economic impact of elk-induced pasture loss to range from USD \$3.56-\$91.20 $\mathrm{ha}^{-1} \mathrm{yr}^{-1}$ with a median value of $\$ 20.94 \mathrm{ha}^{-1} \mathrm{yr}^{-1}$ (Fig. 4), equivalent to roughly $\$ 10,900$ for the median property size in our sample. Costs were relatively higher in Del Norte, which is likely a function of the larger AUE of Roosevelt elk (they are considerably larger than Mendocino's Tule elk subspecies) and their tendency for full-year residency in high densities on Del Norte properties (Fig. 3).

Fig. 4. The economic impact of elk-induced pasture loss for beef and dairy producers on the North Coast.

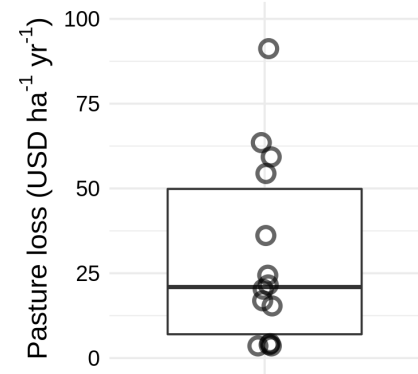

All ranchers (beef and dairy producers) considered pasture loss to be a threat to their operations and they reported the consequences in several ways. One interviewee attributed decreasing cattle weights to recent competition with elk, and two others were forced to reduce their cattle herd size. As one rancher explains, "say I give up 60 calves a year and we'll just throw a number out there... $\$ 800$ [per calf] ... and some years they're worth a lot more than that, that's $\$ 48,000$ of direct loss right there." These losses are incurred while fixed costs of operating the ranch stay the same or are increased due to infrastructure damages from elk (see below).

In addition to direct pasture losses, the inability to control elk movements and the timing of elk grazing create more nuanced difficulties. Unprompted, five ranchers mentioned that elk grazed pastures they were trying to rest, thus reducing the effectiveness of rotational grazing plans by inhibiting pasture recovery. Three ranchers said that elk thwarted reseeding efforts because elk grazed the new growth before it became established. As one rancher explains, "We have no controls, so we're seeing a decline in our forage base and the quality of our forage base."

Landowners experimented with a variety of mitigation tactics for reducing elk occupancy of their land, most of which they reported were ineffective. Scare cannons and motion lights were only temporarily effective because elk soon disassociated them with danger. Hazing elk out of fields with dogs or vehicles caused extensive fence damage because fleeing elk were more likely to crash through fences. Slowly herding elk off pastures worked without as much fence damage but was not perceived to be a longterm solution because elk would quickly reoccupy pastures.

\section{Fence Damage: Increased Risk and Labor}

All interviewees with fences $(n=14)$ experienced elk-induced fence damage, and it was universally perceived to be a major source of conflict. Fences were mentioned 50 times throughout the 17 interviews, most commonly in the context of elk damage or action required to fix and monitor fences. Ranchers in our sample used barbed wire fences with 3-6 strands, with the top strand 40-50 inches high (perimeter fences were toward the higher end of this range). All ranchers said fence repair was a major cost both in terms of labor and materials. It was difficult for ranchers to estimate the total annual cost of elk-induced fence damage, but all lamented the increased labor needed to intensively monitor fences under heavy elk pressure. Frequent breaches increased the risk of cattle straying onto open roads, causing liability and safety concerns. One rancher who experienced nightly fence breaches had to stop grazing cattle in the affected pasture due to concerns for cattle wandering onto the adjacent road. When asked to quantify the cost of fence damage he said, "The calculation would have to be more of a risk assessment," referring to the risks of a vehicle collision with errant cattle.

The only type of fence that was effective in excluding elk was a 6 -foot-tall woven wire fence that the owner described as " $98 \%$ effective." However, this is not a financially viable option for most landowners, especially in areas adjacent to rivers that experience periodic debris flows. A common mitigation strategy was to lower the top wire of internal fences to ca. 40 in. to facilitate elk movement without damage, and some interviewees begrudgingly left internal gates open while resting pastures. Exterior perimeter barbed wire fences have a legal requirement in California of three strands of a minimum 48 in. height (California Food and Agricultural Code 17121), which affects landowner liability and makes the mitigation approaches of lowering fences unfeasible for perimeter fences.

Even though most ranchers would have preferred to exclude elk, six ranchers experimented with fence crossings designed to facilitate elk movement, acknowledging that full exclusion was not currently logistically or financially feasible. Crossings ranged in complexity from removing wire barbs to constructing " $\mathrm{H}$ frame" crossings with a lowered horizontal beam (Fig. 5). Although crossings mitigated damage for some landowners, none could guarantee that elk would exclusively use them, and many found that elk damaged fences adjacent to crossings. One rancher advised that elk crossings should be placed exactly where they already cross, and another said that if you build a crossing that is too conspicuous, the elk won't use it out of suspicion.

Fig. 5. Example of an "H-frame" elk crossing in Mendocino County.

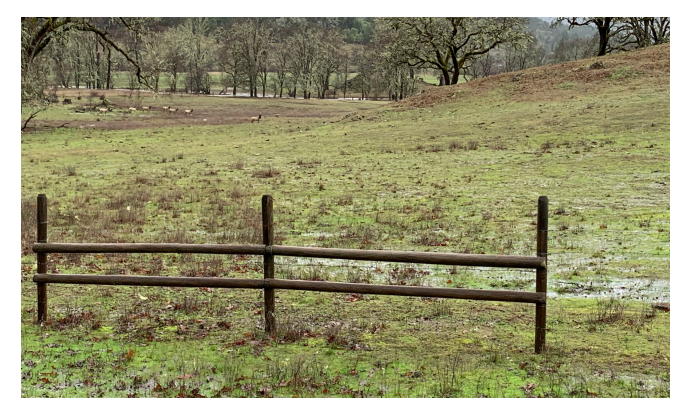




\section{Experiences with Hunting Programs}

The four PLM participants interviewed were generally satisfied with the PLM program and indicated that PLM revenue partially offset elk damages but was not profitable after accounting for habitat restoration requirements and elk damages. One PLM participant disliked the expensive habitat management requirements of his PLM contract (costing \$250,000), but habitat management requirements mostly aligned with landowner goals. Hunting revenue was an order of magnitude higher for PLM participants than for nonPLM participants due to landowner ability to sell bull elk tags to trophy hunters (Fig. 6), indicating that it has greater potential to offset landowner costs, but habitat management expenses and reporting requirements diminished financial benefits. Program participants had the following advice to landowners considering enrollment: (1) understand that a PLM contract is a negotiated process with widely varying habitat improvement requirements, (2) there is extensive compliance paperwork (i.e., transaction costs), and (3) trophy hunters' lofty expectations for expensive hunts can be stressful to manage. In two cases, the PLM contracts created perceived conflicts of interest between neighboring landowners because nonPLM landowners felt that their PLM-enrolled neighbors had less incentive to deter elk from the neighborhood. In sum, PLM revenue can partially offset the cost of elk damage for participants, but eligibility requirements, reporting costs, habitat management, the ad hoc process of negotiating PLM contracts, and a recent reallocation of tags to the SHARE program has limited new participation.

Fig. 6. The reported average hunting revenue per elk for each interviewee. "PLM participants" are interviewees who are enrolled in the Private Lands Management program. NonPLM participants include those enrolled in the Shared Habitat Alliance for Recreational Enhancement (SHARE) program, as well as those who charge trespass fees to hunters who bring their own tags from the general hunting draw.

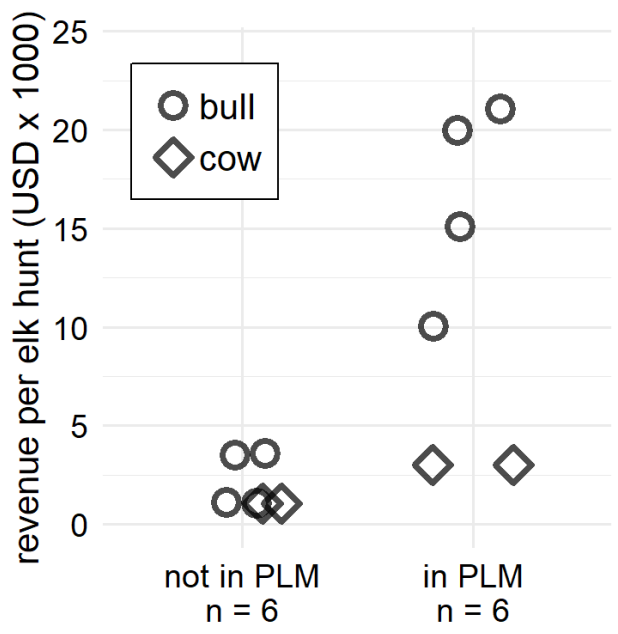

Overall opinions of the SHARE program were mixed. The six SHARE participants in our sample thought the program was better than no hunting, and one dairy owner said people were "real happy with it," but all interviewees thought that current harvest quotas were too low to have a meaningful impact on elk numbers, and no interviewees reported that hunting changed elk behavior in a way that alleviated depredation or fence damage. Six interviewees (three of whom were in SHARE) had concerns about granting public hunters access to their properties through SHARE, primarily because of safety, and this issue was a barrier to participation for three of them. One landowner said that he and his neighbors "just do not like not having the control of who is trespassing on [i.e., accessing through SHARE] their property. And so we're not willing to sign up under a program like this." The majority of landowners had experienced some form of hunter incompetence, and they tried to mitigate safety concerns by orienting hunters to safety hazards on their properties or requiring that hunters were accompanied by the landowner. A few noted that their properties were simply not suitable for hunting, regardless of a program, due to exclusively nocturnal elk occupancy or proximity to roads and houses. The above landowner concerns and observations indicate that SHARE, especially under current harvest quotas, is not perceived as an effective elk damage alleviation tool.

\section{Perceptions of Elk and Elk Management}

The majority of ranchers and dairymen expressed frustration over their financial support of what is perceived as the state's "planted elk" (alluding to the reintroductions). Eight landowners perceived an injustice with reintroduced, state-managed elk consuming privately owned pasture as summarized by one rancher stating: "They're basically saying, well we own them, they're a state animal, wildlife animal, and we can do whatever we damn well please. Landowner, we don't care about you." Despite this perceived injustice and neglect, most landowners conveyed an interest in having elk on the broader landscape and enjoyed seeing them when they first appeared on their properties. The majority of interviewees also said that harvest quotas should have already been drastically raised and that populations were "out of control." Eleven of the 17 interviewees were frustrated by CDFW's perceived lack of action to alleviate elk conflict. This included all interviewed beef and dairy producers in Humboldt and Del Norte Counties. The two timber producers experienced almost zero elk conflict, and ranchers in Mendocino County were comparatively less critical. Two of the Mendocino interviewees did not derive their primary income from ranching, and Mendocino ranches suffered less elk pressure on private land than in Humboldt and Del Norte.

Ten landowners expressed a broader erosion of trust in the state and federal governments' ability to effectively manage land and wildlife resources. Interviewees pointed to fire suppression, forest densification, and lack of grazing on public lands as examples of prior mismanagement, ultimately responsible for increased fire risk, the loss of elk habitat on public land, and subsequent elk pressure on private land. One dairy owner summarized these concerns by saying "Everything has become so overgrown, not just here, but all over California, that a rabbit can't even get through, let alone be supportive for the elk. They aren't managing the land. Period." Landowners also lamented the bureaucratic nature of land and wildlife agencies by citing frequent personnel turnover in CDFW making the agency "faceless," and saying that "the wheels turn so slow," and that "the job description... of all these agencies is really wish washy," such that nothing could get done in the time frame needed to "get a lid" on the elk pressure on private land. Despite the aforementioned qualms, most 
landowners expressed interest in working with the government going forward to try to manage the problem. Ranchers and dairymen viewed cattle grazing as a valuable tool, should managers choose to use it, because when cattle graze they reduce thatch which lowers fire risk and stimulates palatable new growth preferred by elk.

In response to complaints about elk management by landowners, CDFW staff have noted their regulatory mandates in the California Fish and Game Code and their conservation goals outlined in the Elk Management Plan, which states that "When depredation becomes chronic and/or large-scale problems occur involving numerous elk, the Department will emphasize regulated hunting and co-management with Tribes (when appropriate) to alleviate conflicts" (CDFW 2018: 43). The CDFW believed that lawsuits from environmental groups would ensue if they tried to raise recreational harvest quotas without first fulfilling their legal requirement to collect additional years of population data. A recent lawsuit brought against a northern California national park on behalf of local environmental groups was aimed "to keep the Park Service focused on its legal mandate to ensure maximum protection for native wildlife and the natural environment" (Center for Biological Diversity 2016) which indicates that CDFW's concern over lawsuits is warranted. Despite referring to depredation permits as a tool to alleviate elk conflict in public meetings, depredation permits were very rarely issued to interviewees in practice, which is most likely because (1) CDFW has said that they reserve depredation permits for when "... readily identifiable individual animals cause property damage" (CDFW 2018: 172) and (2) because the large number of depredation permits that would be required to stop entire herds of elk depredating pasture is unfeasible under their legal mandate to conserve elk populations for the benefit of the public.

\section{DISCUSSION}

\section{Social-ecological Implications}

Quantifying the direct impacts of wildlife damages is notoriously difficult (Milind et al. 2016), hinders a clearer understanding of the costs of recovering ungulate wildlife populations, and has been identified as a transaction cost in wildlife crop damage compensation programs (Schwerdtner and Gruber 2007, Gren et al. 2018). Yet, attempts to quantify the losses are required to help managers and policy makers better assess the harm and formulate policy. We combined AUEs with landowner reports of elk occupancy to estimate the economic impacts of elk-induced pasture losses. This combination of methods is a novel approach, but is grounded in similar work on wildlife conflict, citizen science (Lee et al. 2006, Kauffman et al. 2016, Vedeld et al. 2016), and the use of AUEs to quantify the costs of forage loss from elk (Torstenson et al. 2002). We found the median annual cost of supporting elk to be $\$ 10,900$ which is consistent with prior estimates using similar techniques for five ranches in Montana which ranged from $\$ 5,949$ to $\$ 21,152$ per ranch per year (Torstenson et al. 2002). Although more than half of interviewees appeared to experience losses over $\$ 20 \mathrm{ha}^{-1} \mathrm{yr}^{-1}$, the results were highly variable (Fig. 4), and there are various sources of error and bias that could impact the estimates. Estimates could be subject to downward biases stemming from imperfect detection (Kéry and Schmidt 2008) in the same way as the minimum total counts conducted by wildlife professionals (Ministry of Environment,
Lands and Parks, Resources Inventory Branch (MELP) 1998, Linnell et al. 2007). Conversely, estimates may be subject to upward biases stemming from landowner anxiety, perception of elk as a threat, and a desire to encourage regulatory change. Despite these potential biases, landowner observations and experiences shape attitudes (Conover 1998), are valuable to incorporate into a better understanding of the social-ecological implications of wildlife conflict, and are shown to be relatively accurate when compared with independent researcher observations of wildlife foraging behavior in the context of crop damage (Spagnoletti et al. 2017). Therefore, we believe our landowner reports provide evidence that elk depredation of pasture has a nonnegligible impact on rancher livelihoods on the North Coast. This method is adaptable to other species for which AUE parameters are known, which includes most bovids, cervids, and equids and is suitable for estimating an initial range of economic impacts to ranchers.

Landowner experience with elk conflict on the North Coast offers critical insight into the difficult task of balancing conservation with impacts to rural livelihoods. Our interviews indicate that the North Coast agricultural community is increasingly impacted by growing elk populations, which are causing pasture losses and fence damage. These findings are congruent with prior studies of elk conflict on rangelands showing that elk depredation of pasture and fence damage are major issues for ranchers (Gerrans 1992, Torstenson et al. 2002, Heydlauff et al. 2006, Hegel et al. 2009). Where row crops are the dominant form of agriculture, fence damage is shown to be less of an issue (Austin et al. 2010, Walberg et al. 2017), perhaps because fences are less common in these areas. Prior surveys on wildlife conflict have established the extent to which direct damage causes negative sentiments toward wildlife (Conover 1998, Walberg et al. 2017), but our semistructured interviews facilitated novel insights by allowing previously undocumented indirect costs and social consequences to emerge through conversation. These included the increased liability risk of cattle escaping through frequently damaged fences, the gradual degradation of pasture conditions, the additional labor required to constantly check fences under heavy elk pressure, and the erosion of trust in state wildlife management (discussed below). Interviewees considered indirect costs to be almost as harmful to their businesses as the direct pasture losses, indicating that future efforts to quantity the economic impact of wild ungulates should consider increased liability risk, labor costs, and trends in pasture conditions associated with ungulate damage. Ninety-five percent of prior wildlife crop damage estimates used market prices of directly damaged goods to determine direct costs only, and none considered the aforementioned indirect effects of damages to crops, pasture, or infrastructure (Gren et al. 2018). Therefore, taking these secondary effects into account would represent a significant change to the way wildlife costs are currently calculated.

The perception among our interviewees that the wildlife agency is "not for the landowner" is consistent with the sentiment of ranchers experiencing elk pressure in Arizona, who believed that the local wildlife agency was "unresponsive to their concerns" (Heydlauff et al. 2006), and survey findings from Minnesota showing that producers within the range of free-roaming elk had less trust in the local wildlife department than those not experiencing elk conflict (Walberg et al. 2017). Our interviews 
were able to more specifically identify where these perceptions of mistrust and frustration originated, highlighting potential pathways toward solutions. For example, ranchers perceived an injustice of reintroduced elk ("the state's elk") disproportionately utilizing their private resources for the benefit of the general public. This finding is an example of how the public trust model of wildlife management (Batcheller et al. 2010) conflicts with notions of private property rights to create antipathy toward wildlife conservation. This tension is likely to occur where any "mobile ecological resource" imparts costs and benefits unequally across the landscape (Austin et al. 2010). Tension and mistrust grow when the level of "perceived congruency of values" between the stakeholder and the manager is low (Riley et al. 2018). Our interviews build upon these insights by showing that perceptions of incongruent values arise when the species causing harm was intentionally reintroduced by the state, where landowners are told that regulatory constraints limit pathways to solutions, and where landowners believe that their broader vision of good land and wildlife management is not shared by local managers. These insights highlight the importance of finding common ground on what "good land and wildlife management" means (Aoyama and Huntsinger 2019), especially in the context of a broadening group of wildlife beneficiaries (Decker et al. 2019) who are affected by elk in different ways, to avoid further eroding social capital and creating cultural backlash against conservation values (Manfredo et al. 2017).

Elk conflict on the North Coast reflects a broader challenge to reconcile global conservation efforts with local wildlife damages. The costs to agriculture are often local and tangible, whereas the wildlife benefits generally accrue more broadly (Vedeld et al. 2016, Yang et al. 2020). In an effort to reconcile these dilemmas, wildlife agencies commonly issue depredation permits, disburse damage compensation payments, help producers take preventive measures to reduce conflict, and use regulated hunting (Wagner et al. 1997, Ravenelle and Nyhus 2017, CDFW 2018). However, our interviews show that depredation permits are not being issued for pasture losses on the North Coast, nor are there compensation programs for elk damages in the state of California, so landowner mitigation options are limited to hazing and recreational hunting that ranchers found largely ineffective. California contrasts with ten states and Canadian provinces that have implemented elk damage compensation programs in the past few decades (Wagner et al. 1997), indicating the extent of the issue as well as the prevalence of state-sponsored damage compensation programs to address it. Despite their prevalence, the effectiveness of crop damage compensation programs is widely debated. Compensation programs suffer from common difficulties with transparently determining eligibility, objectively assessing damages, implementing payment procedures, high transaction costs, and underpaying or overpaying claimants (Karanth et al. 2018, Milind et al. 2016, Wagner et al. 1997). Conversations with wildlife officials on the North Coast suggest that there are not enough financial resources to adequately compensate ranchers through a state-sponsored compensation program even if they were able to overcome the aforementioned challenges.

Damage compensation by itself would be a reactive "solution" to what our interviews indicate is largely a landscape-scale habitat distribution problem. The majority of ranchers we interviewed on the North Coast believed that their land (or the private pastureland of their neighbors) was the primary nutritional resource for observed elk; a claim that is supported by the spatial context of most holdings that were either adjacent to other private pastureland or dense coniferous forest known to have significantly lower levels of dietary digestible energy (Rowland et al. 2018). The widespread concern among landowners that the public land was becoming "overgrown" due to fire suppression and lack of vegetation management is supported by studies showing that forests in our study area have become denser and that conifers have encroached into more open habitats that previously supported forage for ungulates (Cocking et al. 2012, Knight et al. 2020). Changing the landscape-scale distribution of high quality elk forage such that more of it is on public land may reduce pressure on private land while enhancing public access to elk. Although CDFW has primary responsibility for monitoring and sustaining elk herds, they do not have sole jurisdiction over public lands vegetation management. Vegetation management for improved elk habitat on public land requires close collaboration with the National Park Service (NPS) and the United States Forest Service (USFS) who manage most of the public land in our study area.

The CDFW must operate within the confines of its legislative mandates, a finite budget, divergent stakeholder opinions, and ecological uncertainties, which place legal, financial, political, and scientific limitations on options for immediate action. For example, for CDFW to raise harvest quotas requires multiple years of demographic data collection to prove that increased harvests would not jeopardize the wildlife population, which then requires approval from the California Fish and Game Commission, which itself must comply with the wildlife policies laid out by the California State Legislature. Therefore, even though local wildlife officials are on the front lines of a complicated debate between conservation and rural livelihoods, they have limited ability to quickly respond due to regulatory, political, and scientific constraints. These limitations lead to increasing landowner frustration as they seek urgent solutions. Meanwhile, CDFW's elk plan has also been critiqued as "weak on elk recovery and short on science" (Center for Biological Diversity 2018), despite population trends that indicate the contrary (Fig. 1a), indicating that actions to increase elk harvest rates would be met with opposition from environmental groups. These political and institutional challenges are shared by wildlife conservation organizations and agencies throughout the world (Fuller et al. 2020, Davies and White 2012). The pathway to solutions will likely require a clarification of the roles and responsibilities of the multiple institutions involved in creating wildlife policy, the implementation of a transparent, defensible decision-making process that effectively incorporates divergent stakeholder opinions (Fuller et al. 2020), and a broader reconsideration of who should bear the costs of conservation as a society.

\section{Potential Solutions}

Viewing wildlife damage as a negative externality associated with supporting healthy wildlife populations may be a productive framework for crafting balanced policy and process. Past work has described a reciprocal nature to externalities such that if wildlife were removed to alleviate damages to agriculture, it would impose a reciprocal cost to wildlife enthusiasts (Coase 1960, Anderson 1998). Likewise, conservation imposes costs to those 
experiencing damages. Under a Coasean framework, the conflicting parties (in this case wildlife beneficiaries and landowners experiencing conflict) would contract with each other to find an optimal management plan for an area. Although such a "Coasean solution" cannot legally be made with respect to elk in California due to the res nullius status of elk, this framework offers helpful concepts that could facilitate finding common ground or pathways to solutions between stakeholders including: (1) recognizing the reciprocal nature of wildlife externalities, (2) compelling wildlife beneficiaries to consider the costs of wildlife to agricultural producers, and (3) facilitating contracting between wildlife beneficiaries and claimants. For example, in the case of wolf damages to livestock producers in the Greater Yellowstone Ecosystem, Defenders of Wildlife effectively assumed "ownership" and financial liability for the damages by raising public funds from voluntary wildlife enthusiasts to pay for the negative externalities of enjoying free-roaming wolves (Anderson 1998).

We found that hunting revenue under the PLM program is already offsetting some of the damages caused by elk to ranching operations under a pseudo-Coasean framework because ranchers benefit from the right to sell elk hunting experiences (Fig. 6). Where elk hunting was a significant part of the ranching enterprise, net economic harm from elk was reduced and attitudes toward elk were more positive. This is consistent with observations in Oregon finding that fee hunting was profitable enough to serve as a powerful incentive for conservation on private ranchland (Rasker et al. 1992). However, unlike some regulatory frameworks outside the United States where trophy hunting revenue is explicitly used to offset wildlife damages (Bennett et al. 2007, Lindsey et al. 2007, Frost and Bond 2008, Sifuna 2010), most private lands hunting programs in the United States were not designed for wildlife damage compensation or profits (Benson et al. 2001). Transaction costs for entering into the PLM program and fulfilling habitat management requirements are very high, and SHARE landowner participants do not contract directly with hunters and other wildlife beneficiaries, which keeps revenue much lower (Fig. 6). Our interviews suggest that optimizing private lands hunting programs for damage compensation by reducing transaction costs, relaxing eligibility requirements, facilitating private contracting, and increasing tag allowances would likely have the benefits of increasing harvest opportunities for public hunters, helping local producers offset some of the costs of elk damage, and perhaps bringing ranchers' livelihoods into closer alignment with elk.

Despite the revenue potential of elk on private land, successfully wielding it to develop long-term solutions within a Coasean framework alone may be challenging for a number of reasons. First, wildlife is typically not the most economically optimal use of land, and it can be difficult to ensure that future benefits will be captured when the species of interest is highly mobile (Tisdell 2004, Gren et al. 2018). An assessment of public willingness to pay for both nonconsumptive and consumptive (i.e., hunting) enjoyment of elk, such as those reviewed by Philip and Macmillan (2005), would be a useful first step to inform the economic viability of solutions based on Coasean bargaining between ranchers, hunters, and other wildlife enthusiasts. Economic choice experiments have been successfully applied to determine the value assigned to particular consumptive and nonconsumptive enjoyment of elk and elk habitat (Bullock et al. 1998). The second potential challenge is that the elimination of wildlife markets was a milestone of success in the history of wildlife management in the United States, and historical opposition to wildlife markets and hunting revenue is inculcated in American wildlife management philosophies today (Geist 1988, Organ et al. 2012). Therefore, a key question for policy creation is to what extent the use of hunting revenue to offset damages would clash with these philosophies and whether or not it could jeopardize wildlife populations in the modern social-ecological context. Finally, it is possible that new negative externalities would be imparted on neighboring properties (see Olaussen and Skonhoft 2011, Gren et al. 2018) who were not able to sell hunting rights, but still suffered elk damages. This raises two key limitations of Coasean solutions for wildlife conservation: there are typically more than two parties affected by management decisions, and property rights are not always clear. Despite Coasean bargaining as a promising mechanism to offset costs for ranchers, long-term coexistence between ranching, elk, elk hunters, and the nonconsumptive appreciation of elk will also require the support of a more collaborative approach that is conducive to managing a mobile, nonexcludable resource for multiple stakeholders at a landscape scale.

The management of common-pool resources (Ostrom 1990) has the potential to address some of the aforementioned challenges of policies based solely on a Coasean framework. Bullock (1999) identified that red deer (Cervus elaphus) conflict in the UK is a common-pool resource problem by pointing out that there are appropriation problems (dependence on neighbors to "cull marauding animals") and provision problems (landowners not providing feed or shelter in the UK context). The provision problem in California is that landowners cannot regulate how much forage they are provisioning to elk, whereas the state tightly controls elk appropriation on behalf of a largely nonlocal public. The lack of an innate connection between rights (i.e., harvest) and responsibilities (i.e., feeding elk or paying for elk damages) is a recognized issue with managing collective resources (Slaev and Collier 2018), and overcoming it requires implementing two of Ostrom's most relevant principles for the successful management of common-pool resources: (1) "individuals affected by harvesting and protection rules are included in the group who can modify these rules" and (2) "the rights of users to devise their own institutions are not challenged by external governmental authorities" (Becker and Ostrom 1995: 119). Successfully creating local working groups composed of wildlife managers, land managers, ranchers, environmentalists, hunters, and other local stakeholders to devise local management plans would satisfy the first principle and likely result in more adaptive solutions based on local social-ecological conditions. The CDFW is best positioned to initiate the creation of this working group because they are responsible for monitoring elk populations, recommending harvest quotas to the California Fish and Game Commission, and formulating the state's elk management plan with public input. Successfully achieving these functions in a way that maintains public trust and maximizes transparency requires CDFW to be more interactive, collaborative, and communicative, which a working group would facilitate. However, determining the extent to which satisfying Ostrom's second principle is possible in the context of this working group would require outlining the 
scope of decision-making power the working group actually has and to what extent meaningful solutions would require approval from "external governmental authorities."

Our interviews revealed that elk conflict is a landscape-scale issue requiring elk habitat provisioning on public land to help reduce grazing pressure on private land. Therefore, it is essential that the land management agencies who control vegetation management planning on public land (the USFS and the NPS) be included in the collaborative management working groups. Working groups must develop and maintain social capital shown to be essential for collaborative wildlife management (Riley et al. 2018, Smith et al. 2013). "Collaborative management at a landscape scale" has become the "preferred strategy" to manage deer in the UK (Austin et al. 2010), but explicitly addressing options to offset the costs of elk on private land is necessary for building social capital between managers and landowners (Davies and White 2012). We find these prior insights to be especially relevant to our study area where ranchers want to feel more meaningfully involved in wildlife management decision making, know that their concerns are being taken seriously, and have assurances that they will not be relegated to the role of raising wildlife for the public's enjoyment without remuneration. If it is still legally impossible or politically unfeasible for working groups to better align local livelihoods with wildlife through changes in public land management, hunting, ecotourism, or novel forms of damage prevention, then satisfying Ostrom's second principle (higher governmental support) will be especially crucial for pursuing regulatory approval for novel forms of government-sponsored crop and forage compensation programs that minimize transaction costs (Gren et al. 2018) and avoid the pitfalls of prior programs (Karanth et al. 2018, Milind et al. 2016, Wagner et al. 1997).

\section{CONCLUSION}

Our initial investigation of elk conflict in northern California reveals globally relevant themes pertaining to the challenges of finding coexistence between conservation agendas and rural livelihoods. Successful wildlife restoration programs around the world have increased rates of human-wildlife conflict, particularly in agricultural communities. Although wildlife conservation is desperately needed, the costs can accrue locally without proportional benefits, which creates resentment and threatens future conservation efforts. The res nullius status of wildlife in the United States, coupled with state regulatory authority for managing game species, limits landowner options for mitigating damages to on-farm practices that are often ineffective. These experiences, coupled with regulatory hurdles constraining the ability of the local wildlife agency to effectively mitigate elk damages, has caused widespread frustration among beef and dairy interviewees. A combination of enhanced damage reduction tools, financial mechanisms to offset the costs, and a landscape-scale approach to elk habitat management on public land will be important to reduce conflict. Concepts from the management of common-pool resources and Coasean bargaining both show promise for guiding a locally appropriate, collaborative policy-making process for elk conflict resolution.

Responses to this article can be read online at: https://www.ecologyandsociety.org/issues/responses. php/12283

\section{Acknowledgments:}

We would like to thank the landowners and managers who took the time to speak with us about their experiences with elk conflict and management. This publication was made possible in part by support from the Berkeley Research Impact Initiative sponsored by the UC Berkeley Library. Additional support was provided by the University of California Graduate Students in Extension Pilot Program.

\section{Data Availability:}

The data and code used to calculate the economic impact of elkinduced pasture loss is available through the Open Science Framework at https://doi.org/10.17605/OSF.IO/SXJ5C. These data have been modified to remove personally identifying information in accordance with our research protocol approved by the UC Berkeley Office for the Protection of Human Subjects (CPHS Protocol \# 2018-07-11252).

\section{LITERATURE CITED}

Allen, K. E. 2015. Trade-offs in nature tourism: contrasting parcel-level decisions with landscape conservation planning. Ecology and Society 20(1): 21. https://doi.org/10.5751/ ES-07058-200121

Anderson, T. 1998. Viewing wildlife through Coase-colored glasses. Pages 259-282 in P. Hill and R. Meiners, editors. Who owns the environment? Rowman and Littlefield Publishers, Lanham, Maryland, USA.

Aoyama, L., and L. Huntsinger. 2019. Are landowners, managers, and range management academics on the same page about conservation? Rangelands 41(1):61-69. https://doi.org/10.1016/j. rala.2018.10.001

Austin, Z., J. C. R. Smart, S. Yearley, R. J. Irvine, and P. C. L. White. 2010. Identifying conflicts and opportunities for collaboration in the management of a wildlife resource: a mixedmethods approach. Wildlife Research 37(8):647-657. https://doi. org/10.1071/WR10057

Barboza, R. R., S. F. Lopes, W. M. S. Souto, H. FernandesFerreira, and R. R. N. Alves. 2016. The role of game mammals as bushmeat In the Caatinga, northeast Brazil. Ecology and Society 21(2): 2. https://doi.org/10.5751/ES-08358-210202

Batcheller, G. R., M. C. Bambery, L. Bies, T. Decker, S. Dyke, D. Guynn, M. McEnroe, M. O'Brien, J. Organ, S. Riley, and G. Roehm. 2010. The public trust doctrine: implications for wildlife management in the United States and Canada. The Wildlife Society, Bethesda, Maryland, USA.

Becker, C. D., and E. Ostrom. 1995. Human ecology and resource sustainability: the importance of institutional diversity. Annual Review of Ecology and Systematics 26(1):113-133. https://doi. org/10.1146/annurev.es.26.110195.000553

Bennett, E. L., E. Blencowe, K. Brandon, D. Brown, R. W. Burn, G. Cowlishaw, G. Davies, H. Dublin, J. E. Fa, E. J. MilnerGulland, J. G. Robinson, J. M. Rowcliffe, F. M. Underwood, and D. S. Wilkie. 2007. Hunting for consensus: reconciling bushmeat harvest, conservation, and development policy in West and 
Central Africa. Conservation Biology 21(3):884-887. https://doi. org/10.1111/j.1523-1739.2006.00595.x

Benson, D., D. W. Steinbach, R. Shelton, and J. Winn, editors. 2001. Wildlife stewardship and recreation on private lands. Texas A\&M University Press, College Station, Texas, USA.

Bullock, C. H. 1999. Environmental and strategic uncertainty in common property management: The case of Scottish Red Deer. Journal of Environmental Planning and Management 42(2):235252. https://doi.org/10.1080/09640569911235

Bullock, C. H., D. A. Elston, and N. A. Chalmers. 1998. An application of economic choice experiments to a traditional land use - deer hunting and landscape change in the Scottish Highlands. Journal of Environmental Management 52(4):335-351. https://doi.org/10.1006/jema.1997.0179

California Department of Fish and Wildlife (CDFW). 2008. The private lands management (PLM) program policies and procedures handbook. [online] URL: https://nrm.dfg.ca.gov/FileHandler. ashx?DocumentID=83034\&inline

California Department of Fish and Wildlife (CDFW). 2018. Elk conservation and management plan. [online] URL: https://nrm. dfg.ca.gov/FileHandler.ashx?DocumentID=162912\&inline

California Department of Fish and Wildlife (CDFW). $2019 a$. Private lands management (PLM). [online] URL: www.wildlife. ca.gov/Hunting/PLM

California Department of Fish and Wildlife (CDFW). $2019 b$. Shared habitat alliance for recreational enhancement (SHARE). [online] URL: www.wildlife.ca.gov/hunting/share\#51518484elk-hunts

California Department of Fish and Wildlife (CDFW). 2020. Report an elk observation. [online] URL: https://cdfw.maps.arcgis. com/apps/CrowdsourceReporter/index.html?appid=70fc2a0613884088b8f91698df6a4c2f

California Department of Food and Agriculture (CDFA). 2016. California agricultural statistics review 2016-2017. [online] URL: www.cdfa.ca.gov/statistics/PDFs/2015Report.pdf

California Fish and Game Commission (CFGC). 2019. 6 February 2019. [online] URL: https://Videobookcase.Com/ California/Fish-Game-Commission/February-6-2019/

CalLands. 2018. CalLands. University of California Cooperative Extension, Davis, California, USA. [online] URL: https:// callands.ucanr.edu/index.html

Center for Biological Diversity. 2016. Court rules lawsuit over Point Reyes management plan can move forward. [online] URL: https://www.biologicaldiversity.org/news/press_releases/2016/pointreyes-07-19-2016.html

Center for Biological Diversity. 2018. California draft elk management plan lacks science, shortchanges conservation. [online] URL: Www.biologicaldiversity.org/news/press releases/2018/californiaelk-01-29-2018.php

Coase, R. 1960. The problem of social cost. Pages 87-137 in C. Gopalakrishnan, editor. Classic papers in natural resource economics. Palgrave Macmillan, London, UK. https://doi. org/10.1057/9780230523210_6
Cocking, M. I., J. M. Varner, and R. L. Sherriff. 2012. California black oak responses to fire severity and native conifer encroachment in the Klamath Mountains. Forest Ecology and Management 270:25-34. https://doi.org/10.1016/j.foreco.2011.12.039

Conover, M. R. 1998. Perceptions of American agricultural producers about wildlife on their farms and ranches. Wildlife Society Bulletin 26(3):597-604.

Conover, M. R., W. C. Pitt, K. K. Kessler, T. J. Dubow, and W. A. Sanborn. 1995. Review of human injuries, illnesses, and economic losses caused by wildlife in the United States. Wildlife Society Bulletin (1973-2006) 23(3):407-414.

Crosman, K. M., E. L. Petrou, M. B. Rudd, and M. D. Tillotson. 2019. Clam hunger and the changing ocean: characterizing social and ecological risks to the quinault razor clam fishery using participatory modeling. Ecology and Society 24(2): 16. https://doi. org/10.5751/ES-10928-240216

Danielsen, F., N. D. Burgess, A. Balmford, P. F. Donald, M. Funder, J. P. G. Jones, P. Alviola, D. S. Balete, T. Blomley, J. Brashares, B. Child, M. Enghoff, J. Fjeldså, S. Holt, H. Hübertz, A. E. Jensen, P. M. Jensen, J. Massao, M. M. Mendoza, Y. Ngaga, M. K. Poulsen, R. Rueda, M. Sam, T. Skielboe, G. Stuart-Hill, E. Topp-Jørgensen, and D. Yonten. 2009. Local participation in natural resource monitoring: a characterization of approaches. Conservation Biology 23(1):31-42. https://doi.org/10.1111/ j.1523-1739.2008.01063.X

D’Anna, L. M., and G. D. Murray. 2015. Perceptions of shellfish aquaculture in British Columbia and implications for well-being in marine social-ecological systems. Ecology and Society 20(1): 57. https://doi.org/10.5751/es-07319-200157

Davies, A. L., and R. M. White. 2012. Collaboration in natural resource governance: reconciling stakeholder expectations in deer management in Scotland. Journal of Environmental Management 112:160-169. https://doi.org/10.1016/j.jenvman.2012.07.032

Decker, D. J., A. B. Forstchen, W. F. Siemer, C. A. Smith, R. K. Frohlich, M. V. Schiavone, P. E. Lederle, and E. F. Pomeranz. 2019. Moving the paradigm from stakeholders to beneficiaries in wildlife management. The Journal of Wildlife Management 83 (3):513-518. https://doi.org/10.1002/jwmg.21625

Devore, R. M., M. J. Butler, M. C. Wallace, S. L. Liley, A. A. Mertz, S. E. Sesnie, and P. S. Gipson. 2016. Elk resource selection patterns in a semiarid riparian corridor. Journal of Wildlife Management 80(3):479-489. https://doi.org/10.1002/jwmg.1040

Faulkner, S. L., and S. P. Trotter. 2017. Data saturation. Pages 441-442 in J. Matthes, C. S. Davis, and R. F. Potter, editors. The international encyclopedia of communication research methods. Wiley, London UK. https://doi.org/10.1002/9781118901731. iecrm0060

Favre, D. 2003. American wildlife law-an introduction. Animal Legal and Historical Web Center, Michigan State University, East Lansing, Michigan, USA. [online] URL: https://www.animallaw. info/article/american-wildlife-law-introduction

Flaherty, K. L., P. J. Turk, and J. T. Anderson. 2019. Comparing stakeholder attitudes toward white-tailed deer and rare plant management in Canaan Valley, West Virginia. Global Ecology and Conservation 17: e00519. https://doi.org/10.1016/j.gecco.2018. $\underline{\mathrm{e} 00519}$ 
Frost, P. G. H., and I. Bond. 2008. The CAMPFIRE programme in Zimbabwe: payments for wildlife services. Ecological Economics 65(4):776-787. https://doi.org/10.1016/j.ecolecon.2007.09.018

Fuller, A. K., D. J. Decker, M. V Schiavone, and A. B. Forstchen. 2020. Ratcheting up rigor in wildlife management decision making. Wildlife Society Bulletin 44(1):29-41. https://doi. org/10.1002/wsb.1064

Geist, V. 1988. How markets in wildlife meat and parts, and the sale of hunting privileges, jeopardize wildlife conservation. Conservation Biology 2(1):15-26. https://doi.org/10.1111/j.1523-1739.1988. $\underline{\text { tb00331.x }}$

Gerrans, J. 1992. The habitat partnership program in Colorado. Rangelands 14:84-87.

Gogan, P. J., McCrea A. Cobb, N. B. Gates, and R. H. Barrett. 2013. Re-introduction of tule elk to Point Reyes National Seashore, California, USA. Pages 168-173 in P. S. Soorae, editor. Global re-introduction perspectives: further case studies from around the globe. IUCN/SSC Re-introduction Specialist Group, Environment Agency, Abu Dhabi, United Arab Emirates.

Gooding, R. M., and R. K. Brook. 2014. Modeling and mitigating winter hay bale damage by elk in a low prevalence bovine tuberculosis endemic zone. Preventive Veterinary Medicine 114 (2):123-131. https://doi.org/10.1016/j.prevetmed.2014.01.005

Gren, I., T. Häggmark-Svensson, K. Elofsson, and M. Engelmann. 2018. Economics of wildlife management-an overview. European Journal of Wildlife Research 64(2):22. https:// doi.org/10.1007/s10344-018-1180-3

Harper, J. A., J. H. Harn, W. W. Bentley, and C. F. Yocom. 1967. The status and ecology of the Roosevelt elk in California. Wildlife Monographs 16:3-49

Hegel, T. M., C. C. Gates, and D. Eslinger. 2009. The geography of conflict between elk and agricultural values in the Cypress Hills, Canada. Journal of Environmental Management 90(1):222235. https://doi.org/10.1016/j.jenvman.2007.09.005

Herman-Mercer, N. M., E. Matkin, M. J. Laituri, R. C. Toohey, M. Massey, K. Elder, P. F. Schuster, and E. A. Mutter. 2016. Changing times, changing stories: generational differences in climate change perspectives from four remote indigenous communities in subarctic Alaska. Ecology and Society 21(3): 28. https://doi.org/10.5751/ES-08463-210328

Heydlauff, A. L., P. R. Krausman, W. W. Shaw, and S. E. Marsh. 2006. Perceptions regarding elk in northern Arizona. Wildlife Society Bulletin 34(1):27-35. https://doi.org/10.2193/0091-7648 (2006)34[27:PREINA]2.0.CO;2

Huang, R. 2018. RQDA: R-based qualitative data analysis. [online] URL: http://rqda.r-forge.r-project.org

Humboldt County Department of Agriculture (HCDA). 2016. 2016 Crop report. [online] URL: https://humboldtgov.org/ DocumentCenter/View/61579/2016-CROP-REPORT?bidId=

Ilker, E., S. A. Musa, and R. S. Alkassim. 2016. Comparison of convenience sampling and purposive sampling. American Journal of Theoretical and Applied Statistics 5(1):1-4.
Karanth, K. K., S. Gupta, and A. Vanamamalai. 2018. Compensation payments, procedures and policies towards human-wildlife conflict management: Insights from India. Biological Conservation 227:383-389. https://doi.org/10.1016/j. biocon.2018.07.006

Kauffman, M., D. Peck, B. Scurlock, J. Logan, T. Robinson, W. Cook, K. Boroff, B. Schumaker. 2016. Risk assessment and management of brucellosis in the southern greater Yellowstone area (I): a citizen-science based risk model for bovine brucellosis transmission from elk to cattle. Preventive Veterinary Medicine 132:88-97. https://doi.org/10.1016/j.prevetmed.2016.08.004

Kéry, M., and B. R. Schmidt. 2008. Imperfect detection and its consequences for monitoring for conservation. Community Ecology 9(2):207-216. https://doi.org/10.1556/comec.9.2008.2.10

Knight, C. A., C. V Cogbill, M. D. Potts, J. A. Wanket, and J. J. Battles. 2020. Settlement-era forest structure and composition in the Klamath Mountains: reconstructing a historical baseline. Ecosphere 11(9): e03250. https://doi.org/10.1002/ecs2.3250

Lee, T., M. S. Quinn, and D. Duke. 2006. Citizen, science, highways, and wildlife: using a web-based GIS to engage citizens in collecting wildlife information. Ecology and Society 11(1): 11. [online] URL: http://www.ecologyandsociety.org/vol11/iss1/ $\underline{\operatorname{art11/}}$

Lindsey, P. A., L. G. Frank, R. Alexander, A. Mathieson, and S. S. Romañach. 2007. Trophy hunting and conservation in africa: problems and one potential solution. Conservation Biology 21 (3):880-883. https://doi.org/10.1111/j.1523-1739.2006.00594.X

Linnell, J. D. C., J. Odden, R. Andersen, H. Brøseth, H. Andrén, O. Liberg, P. Ahlqvist, P. Moa, T. Kvam, P. Segerström, K. Schmidt, W. Jędrzejewski, and H. Okarma. 2007. Distance rules for minimum counts of Eurasian lynx Lynx Lynx family groups under different ecological conditions. Wildlife Biology 13(4):447455. https://doi.org/10.2981/0909-6396(2007)13[447:drfmco]2.0. $\underline{\mathrm{co} ; 2}$

Manfredo, M. J., T. L. Teel, L. Sullivan, and A. M. Dietsch. 2017. Values, trust, and cultural backlash in conservation governance: the case of wildlife management in the United States. Biological Conservation 214(4):303-311. https://doi.org/10.1016/j.biocon.2017.07.032

Milind, M., K. Patel, A. Bayani, and P. Patil. 2016. A theoretical model of community operated compensation scheme for crop damage by wild herbivores. Global Ecology and Conservation 5:58-70. https://doi.org/10.1016/j.gecco.2015.11.012

Ministry of Environment, Lands and Parks, Resources Inventory Branch (MELP). 1998. Ground-based inventory methods for selected ungulates: moose, elk and deer. Province of British Columbia, Vancouver, British Columbia, Canada. [online] URL: https://www2.gov.bc.ca/assets/gov/environment/natural-resourcestewardship/nr-laws-policy/risc/grndb.pdf

Minnesota Department of Agriculture (MNDA). 2020. Compensation for crop damage caused by elk. Minnesota Department of Agriculture, St. Paul, Minnesota, USA. [online] URL: https://www.mda.state.mn.us/business-dev-loans-grants/ compensation-crop-damage-caused-elk 
Nahuelhual, L., F. Benra Ochoa, F. Rojas, G. Ignacio Diaz, and A. Carmona. 2016. Mapping social values of ecosystem services: what is behind the map? Ecology and Society 21(3): 24. https:// doi.org/10.5751/es-08676-210324

Natural Resources Conservation Service (NRCS). 2006. Animal unit equivalent guide. Natural Resources Conservation Service, USDA, Washington, D.C., USA. [online] URL: https://www.nres. usda.gov/Internet/FSE DOCUMENTS/nrcs144p2 051957.pdf

Nevada Department of Wildlife (NDW). 2020. Incentive and compensation maps. Nevada Department of Wildlife, Reno, Nevada, USA. [online] URL: http://www.ndow.org/Hunt/ Regulations_Licenses_Tags_Permits/Incentive_and_Compensation_Maps/

Nyhus, P. J. 2016. Human-wildlife conflict and coexistence. Annual Review of Environment and Resources 41(1):143-171. https://doi.org/10.1146/annurev-environ-110615-085634

Olaussen, J. O., and A. Skonhoft. 2011. A cost-benefit analysis of moose harvesting in Scandinavia. A stage structured modelling approach. Resource and Energy Economics 33(3):589-611. https:// doi.org/10.1016/j.reseneeco.2011.01.001

Oregon State Legislature. 2020. House Bill 3227. Oregon State Legislature, Salem, Oregon, USA. [online] URL: https://olis.leg. state.or.us/liz/2019R1/Measures/Overview/HB3227

Organ, J. F., V. Geist, S. P. Mahoney, S. Williams, P. R. Krausman, G. R. Batcheller, T. A. Decker, R. Carmichael, P. Nanjappa, R. Regan, R. A. Medellin, R. Cantu, R. E. Mccabe, S. Craven, G. M. Vecellio, D. J. Decker, T. A. Bookhout, and T. Rentz. 2012. The North American model of wildlife conservation. Technical Review 12-04, The Wildlife Society, Bethesda, Maryland, USA.

Ostrom E. 1990. Governing the commons. Cambridge University Press, Cambridge, UK.

Philip, L. J., and D. C. MacMillan. 2005. Exploring values, context and perceptions in contigent valuation studies: The CV Market Stall technique and willingness to pay for wildlife conservation. Journal of Environmental Planning and Management 48(2):257274. https://doi.org/10.1080/0964056042000338172

Rasker, R., M. V. Martin, and R. L. Johnson. 1992. Economics: theory versus practice in wildlife management. Conservation Biology 6(3):338-349. https://doi.org/10.1046/j.1523-1739.1992.06030338. $\underline{x}$

Ravenelle, J., and P. J. Nyhus. 2017. Global patterns and trends in human-wildlife conflict compensation. Conservation Biology 31(6):1247-1256 https://doi.org/10.1111/cobi.12948

Riley, S. J., J. K. Ford, H. A. Triezenberg, and P. E. Lederle. 2018. Stakeholder trust in a state wildlife agency. Journal of Wildlife Management 82(7):1528-1535. https://doi.org/10.1002/jwmg.21501

Robb, B., and G. Bethge. 2001. The ultimate guide to elk hunting. The Lyons Press, Guilford, Connecticut, USA.

Rocky Mountain Elk Foundation (RMEF). 2019. Elk facts. Rocky Mountain Elk Foundation, Missoula, Montana, USA. [online] URL: http://www.rmef.org/ElkFacts

Rowland, M. M., M. J. Wisdom, R. M. Nielson, J. G. Cook, R. C. Cook, B. K. Johnson, P. K. Coe, J. M. Hafer, B. J. Naylor, D.
J. Vales, R. G. Anthony, E. K. Cole, C. D. Danilson, R. W. Davis, F. Geyer, S. Harris, L. L. Irwin, R. McCoy, M. D. Pope, K. SagerFradkin, and M. Vavra. 2018. Modeling elk nutrition and habitat use in western Oregon and Washington. Wildlife Monographs 199 (1):1-69. https://doi.org/10.1002/wmon.1033

Sayre, N. F. 2004. The need for qualitative research to understand ranch management. Journal of Range Management 57(6):668-74.

Schwerdtner K., and B. Gruber. 2007. A conceptual framework for damage compensation schemes. Biological Conservation 134:354-360 https://doi.org/10.1016/j.biocon.2006.08.010

Sifuna, N. 2010. Wildlife damage and its impact on public attitudes towards conservation: a comparative study of Kenya and Botswana, with particular reference to Kenya's Laikipia Region and Botswana's Okavango Delta Region. Journal of Asian and African Studies 45(3):274-296. https://doi.org/10.1177/0021909610364776

Slaev, A. D., and M. Collier. 2018. Managing natural resources: Coasean bargaining versus Ostromian rules of common governance. Environmental Science and Policy 85(March):47-53. https://doi.org/10.1016/j.envsci.2018.03.017

Smith, J. W., J. E. Leahy, D. H. Anderson, and M. A. Davenport. 2013. Community/agency trust: a measurement instrument. Society and Natural Resources 26(4):472-477. https://doi. org/10.1080/08941920.2012.742606

Spagnoletti, N., T. C. M. Cardoso, D. Fragaszy, and P. Izar. 2017. Coexistence between humans and capuchins (Sapajus libidinosus): comparing observational data with farmers' perceptions of crop losses. International Journal of Primatology 38(2):243-262. https://doi.org/10.1007/s10764-016-9926-9

State of California. 2007. California Fish and Game Code 4181. Article 2 Depredators, Section 4180-4190. State of California, Sacramento, California, USA. [online] https://leginfo.legislature. ca. gov/faces/codes displayText.xhtml?lawCode=FGC\&division=4 . \&title $=\&$ part $=3 . \&$ chapter $=3 . \&$ article $=2$.

Stewart, C. M., W. J. McShea, and B. P. Piccolo. 2007. The impact of white-tailed deer on agricultural landscapes in 3 national historical parks in Maryland. Journal of Wildlife Management 71 (5):1525-1530. https://doi.org/10.2193/2006-351

Tisdell, C. 2004. Economic incentives to conserve wildlife on private lands: analysis and policy. The Environmentalist 24:153163. https://doi.org/10.1007/s10669-005-6049-9

Torstenson, W. L. F., M. W. Tess, and J. E. Knight. 2002. Elk management strategies and profitability of beef cattle ranches. Journal of Range Management 55(2):117-126.

University of California Cooperative Extension (UCCE). 2019. County rangeland acreage. University of California Cooperative Extension, Davis, California, USA. [online] URL: http:// rangelandarchive.ucdavis.edu/Online_Learning_Resources/_file196534_

van Tassell, L. W., C. Phillips, and B. Z. Yang. 1999. Depredation claim settlements in Wyoming. Wildlife Society Bulletin 27 (2):479-487. 
Vedeld, P., C. Cavanagh, J. Petursson, C. Nakakaawa, R. Moll, and E. Sjaastad. 2016. The political economy of conservation at Mount Elgon, Uganda: between local deprivation, regional sustainability, and global public goods. Conservation and Society 14(3):183-194 https://doi.org/10.4103/0972-4923.191155

Wagner, K. K., R. H. Schmidt, and M. R. Conover. 1997. Compensation programs for wildlife damage in North America. Wildlife Society Bulletin 25(2):312-319.

Walberg, E., G. J. D’Angelo, and L. Cornicelli. 2017. Landowner attitudes toward elk in northwest Minnesota. Minnesota Department of Natural Resources, St. Paul, Minnesota, USA. [online] URL: https://files.dnr.state.mn.us/wildlife/research/ summaries/hd/2016_elk-landowner-attitudes.pdf

Washington Department of Fish and Wildlife (WDFW). 2018. North Cascades elk management update. Washington Department of Fish and Wildlife, Olympia, Washington, USA. [online] https:// app.leg.wa.gov/ReportsToTheLegislature/Home/GetPDF?fileName= Proviso $\% 20$ North $\% 20$ Cascades $\% 20$ Elk $\% 20$ Herd $\%$ 20Update f5544137-6cd0-4ad4-bf80-ee5e5979d6c3.pdf

Wisconsin Farm Bureau. 2020. Program offers compensation for crop, livestock producers experiencing wildlife damage. Wisconsin Farm Bureau, Madison, Wisconsin, USA. [online] URL: https:// wfbf.com/ag-newswire/program-offers-compensation-for-crop-livestockproducers-experiencing-wildlife-damage/

Yang, H., F. Lupi, J. Zhang, and J. Liu. 2020. Hidden cost of conservation: a demonstration using losses from human-wildlife conflicts under a payments for ecosystem services program. Ecological Economics 169: 106462. https://doi.org/10.1016/j. ecolecon.2019.106462

Yoder, J. 2002. Deer-inflicted crop damage and crop choice in Wisconsin. Human Dimensions of Wildlife 7(3):179-196. https:// doi.org/10.1080/10871200260293342 
Appendix 1. Interview Guide

\section{Interview Guide}

Elk in Northern California: Costs, Benefits, and Perceptions

Format and Process - This will be a semi-structured interview $30 \mathrm{~min}$ to 1 hour. Based on the interviewee's responses, there may be some topical diversions from the guide. However, the larger themes and objectives of the interview will remain the same.

Recording - The interview will be recorded for future transcription (if participants consent) and some notes will be taken during the interviews. The recorded interviews will be secured according to the confidentiality and data security procedures outlined in section 13 of this IRB protocol.

Research Question - The objective of this research is to understand and describe the conflicts and benefits that elk bring to land owners and other stakeholders in northern California.

1) What are the economic implications of elk-induced infrastructural damage and competition with livestock for forage on rangeland? What are the other costs and benefits of elk (monetary or non-monetary)?

2) Does elk hunting provide significant revenue to landowners?

The rationale for engaging in this line of research is that it will help land owners, policy makers, wildlife managers, and the general public to better understand elk-human interactions and find solutions to elk-related problems.

\section{Personnel and Property Characteristics}

Are you an:

Owner/Operator?

Lessee?

What are the Main Activities on your ranch and percentage of income from each? Average over past 5 years.

Livestock production

Fee hunting

Crop/hay production 
Timber production

Investment property - Capital Gains

Other, such as:

Mineral leases

Cell tower leases

Firewood sale

Bird watching

Horse training

Bed and Breakfast

Events - weddings, etc.

What land area of the property is engaged in each productive activity (percent or absolute values)?

\section{Presence of Elk}

Do you have elk on your property? If yes,

\begin{tabular}{|l|l|l|}
\hline Season & $\begin{array}{l}\text { \# of elk on } \\
\text { property }\end{array}$ & $\begin{array}{l}\text { average \# of days per } \\
\text { season elk spend on } \\
\text { property } \\
\text { (\# of days out of 90) }\end{array}$ \\
\hline $\begin{array}{l}\text { Winter (Dec, Jan, } \\
\text { Feb) }\end{array}$ & & \\
\hline $\begin{array}{l}\text { Spring (Mar, Apr, } \\
\text { May) }\end{array}$ & & \\
\hline $\begin{array}{l}\text { Summer (Jun, Jul, } \\
\text { Aug) }\end{array}$ & & \\
\hline Fall (Sept, Oct, Nov) & & \\
\hline
\end{tabular}


Is elk activity focused in any particular area of the property, or dispersed widely across the majority of the property? If it is focused on one area, where on the property is it focused, and what are the habitat attributes of that area?

\section{Livestock Factors}

What is the stocking rate of livestock?

Do elk occupy the same areas as livestock?

Has the presence of elk negatively affected livestock herd health? If yes, how?

\section{Elk-Induced Economic Losses}

Do elk interfere with your operation?

Do elk cause economic losses to your operation? If so, how? Can you estimate the cost of elk-induced economic losses?

Do elk on your property consume forage that is intended for livestock? Can you quantify how much time you think elk spend foraging on your property?Given a mature elk is .6 AUMs, can you estimate the number of AUMs consumed by elk?

Do elk cause damage to infrastructure?

Are there any other ways in which elk interfere with your operation?

Damage to crops?

Other?

\section{Mitigation Practices}

Do you engage in practices designed to deter or mitigate elk damage? If so, what? 


\section{Elk Hunting and Management}

Do you derive benefits from elk hunting on your land?

Are you able to get sufficient elk tags for hunting on your property?

Do you have a fee hunting operation: why or why not?

If you don't have fee hunting

Prefer to keep hunting and/or recreation on ranch for family and friends

Don't like the idea of hunting

Don't want hunters on the ranch

Too much risk of an injury, accident, or lawsuit

Loss of privacy

Don't want to deal with the hassle

Ranch not big enough for fee hunting

Not enough wildlife numbers or species

Income won't offset costs

Don't need added income

Difficulty getting hunters

Other

If you do have fee hunting

Increased income?

It's what the land is meant for

Hunters help maintain aspects of the property, infrastructure maintenance etc.

Prevent hunters from asking for free hunts

Trespass control

Offset forage loss or property damage made by wildlife

Public relations benefits 
Are you involved in a cooperative agreement with neighbors to manage elk or other wildlife?

Do you do predator control?

Harvest

Do you track the harvests of elk on the ranch?

If so,

Quantity harvested

Do you track the characteristics of harvested elk?

B\&C score?

Antler characteristics?

Weight

Age

Do you have sex ratio goals in place? If so, do tag allocations limit your acquisition of these goals?

Do you have age structure goals in place?

If not,

Do you have harvest guidelines/rules? If yes,

How do you set harvest guidelines/rules?

Allow hunters to set rules

Use experience and knowledge of area to set harvest

Use population counts to estimate population and set harvest

Proportion of total elk population harvested over previous 5 and 10 years?

\section{Hunting Enterprise Characteristics (if they have one)}


Lease Type: circle all that apply.

Day/ Multi-day

Season

year-round

multi-year

Do you use an outfitter to manage your hunting?

Do you offer hunting based on:

Single Species

Multiple species

Direct payment for animal harvested

Do you have a corporate entity or a group of private individuals leasing the hunting rights?

Corporate

Private individuals

Other

Number of paying hunters?

Number of hunters allowed to hunt for free? Including yourself, family and friends.

\section{Other Elk Benefits and Costs}

Are there non-monetary benefits to having elk on your land? Intrinsic value?

Other value?

Are elk a net benefit, net liability, or neutral for your property?
A. Benefit
B. Liability 
C. Neutral

Are there circumstances where you could see elk becoming a net benefit due to changes in policies? If so what would they be?

\section{Personal Background}

Ranch is only source of income / Have outside job

How long has property been in family?

How long have you managed the property? 
Appendix 2. Parameters used for estimating the economic impact of elk-induced pasture loss.

Table A2.1. Fixed parameters for pasture loss calculations. Animal unit equivalents (AUEs) are defined as fractions of what a 1,000 pound beef cow (with calf) consumes (NRCS 2006).

\begin{tabular}{|c|c|c|}
\hline Parameter & $\begin{array}{l}\text { Animal Unit } \\
\text { Equivalent } \\
\text { (AUE) }\end{array}$ & Derivation and sources \\
\hline AUE for Roosevelt elk & 0.8 & $\begin{array}{l}\text { Average female Roosevelt elk weight }=600 \\
\text { pounds }(\text { RMEF 2019) } \\
\text { Average male Roosevelt elk weight }=900 \\
\text { pounds (RMEF 2019) } \\
\text { Assumed sex ratio }=0.5 \text { (Weaver and Weckerly } \\
2011 \text { ) } \\
\text { Average Roosevelt elk on the landscape }=600+ \\
900 / 2=750 \text { pounds } \\
750 \text { pounds = } 0.8 \text { AUEs (NRCS 2006) }\end{array}$ \\
\hline AUE for Tule elk & $\$ 25 \mathrm{AUM}^{-1}$ & $\begin{array}{l}\text { Average female Tule elk weight }=400 \text { pounds } \\
\text { (CDFW 2018) } \\
\text { Average male Tule elk weight }=700 \text { pounds } \\
\text { (CDFW 2018) } \\
\text { Assumed sex ratio }=0.5 \\
\text { Average Tule elk on the landscape }=400+700 / 2 \\
=550 \text { pounds } \\
550 \text { pounds }=0.6 \text { AUEs (NRCS 2006) } \\
\text { (CDFA 2016) }\end{array}$ \\
\hline
\end{tabular}

